\title{
FOUCAULT'S GENEALOGY OF HOMOSEXUALITY
}

One Saturday afternoon when I was twelve years old and bored, I picked up a copy of my mother's Ladies' Home Journal and began to read. As usual, I came across a word I did not know, so I trudged into the kitchen and asked my mother: "What is a homosexual?" First she gave me a look that let me know no dialogue on the subject could possibly ensue, and then she gave me a one-sentence answer that, despite its condemnatory tone, made no reference to sexual activity of any sort. I wandered away, confused and deeply troubled.

Ten years later I picked up a copy of Michel Foucault's The History of Sexuality, Volume $1^{1}$ and began to read--at first with interest, then with enthusiasm, and finally with an excitement that intensified with every turn of the page. I finished the book in one day. That evening at a party I spoke of nothing else, though I could not explain to anyone's satisfaction why I was so taken with a 159-page book that made no reference to sexual activity of any sort.

Another ten years have passed. It is now almost twenty-one years since the brief exchange with my mother in the kitchen. In those twenty-one years I have not suffered for lack of answers to my question: "What is a homosexual?" Quite the contrary, I have suffered because of the answers, under the weight of the answers, in the harsh light of the answers, by being required to instantiate the answers.

A question, as Heidegger observed, opens onto the world. There are ways of answering questions that bring that opening to a sudden close, and there are ways of answering--pursuing answers, pursuing the questions themselves--that keep opening open, that keep possibility alive. My excitement over Foucault's work arose from its approach to the question of homosexuality, an approach that--unlike any other I had ever been subjected to--did not halt thinking before it got underway. Though I could not explain why, I knew the day I first read The History of Sexuality that I held in my hands a key to a kind of freedom.

This essay is a reading of The History of Sexuality from the perspective of the question, "What is a homosexual?" It is an attempt to offer an explanation for the excitement this book has held for me for over

'Michel Foucault, The History of Sexuality, Volume 1: An Introduction, trans. Robert Hurley (New York: Vintage Books, 1978). Hereafter references to and quotations from this volume will be givien in the body of the text as $H S 1$ and page number. 
ten years. It is an attempt to show how Foucault's answers work to open questioning and possibilities rather than to foreclose them, to show in what ways Foucault's work is liberating, freeing. Most importantly, the essay itself is a practice of freedom, in Foucault's sense. It is a practice of the freedom Foucault's work produces as one undergoes the power of its genealogical dispersions.

\section{Foucault's Characterization of Sexual Subjectivity}

In The History of Sexuality, Volume 1, Foucault makes three interrelated descriptive claims about contemporary sexuality. First, he asserts that in the West at least since the nineteenth century, sexuality has functioned as a sort of essence, as the name for what lies at the root of any given human life and any given society; it is the foundation of subjectivity. Sexuality is our most fundamental truth, and, as truth, it both marks and occupies an epistemic field. For it is possible, theoretically at least, to know the truth of sexuality, to take it as an epistemic object and interrogate it.

Second, however, this power that pervades us, this essence that grounds us singly and socially, this truth of our subjectivity is not under our control. We do not choose our sexuality; on the contrary, it chooses us. It shapes us, makes us who we are, and yet remains profoundly other to our rationality and our civility. It thus poses a perpetual danger. We must protect and nurture our sexuality, but we must also beware of it as a force capable of destroying what it enables us to create. Hence, sexuality becomes

\footnotetext{
an object of great suspicion; the general and disquieting meaning that pervades our conduct and our existence, in spite of ourselves; the point of weakness where evil portents reach through to us; the fragment of darkness that we each carry within us: a general signification, a universal secret, an omnipresent cause, a fear that never endHS1 69)
}

As the ground of meaning and even of our very existence, sexuality is to be respected, but it is also to be feared.

Third, given that sexuality is our truth and that it endangers as surely as it enables, sexuality not only can be taken as an object of epistemic investigation; it must be so taken. Like nature itself, which both engenders and destroys, sexuality must be understood. By whatever means necessary, we must ensure that sexuality becomes known, that it steps into the light of reason and, to the extent possible, submits itself to managerial judgment. Sexuality, in the person of the sexual subject, must be brought 
to confess.

In short, sexuality is the name of who we are. Simultaneously, it is the name of what most threatens us and what we most need to know.

To North Americans and Western Europeans at the end of the twentieth century, these assertions will seem obvious and commonplace. That sexuality is fundamental to human being--both as individual and as species--will be taken as unproblematic. We are, essentially, sexual beings. Sexuality is a fact. It is the basis of social interaction and the core of individual identity. It poses a threat when its importance goes unrecognized and its expressions are repressed. Therefore, we ought to affirm our sexuality by calling upon it to speak, and we ought to manage its more dangerous potentials through the transformative power of confessional discourse. The greater danger is silence. These assertions are so obvious to most people that questioning them seems reactionary if not insane. Repressed sexuality is self-destructive, debilitating, unhealthy; confession is healthy, liberating, and self-affirmative. Who would doubt these things?

Of course, if one is homosexual, confession's benefits also have their price. One stands to lose one's job, one's home, one's children, one's medical insurance, one's civil rights, and (especially if one is under-aged or institutionalized) one's physical self-determination and physiological integrity. Sometimes that price seems so high that one does begin to doubt; one begins to suspect that the demand for confession originates someplace other than in a desire for liberation--or that the liberation desired is liberation from, among other things, homosexuality.

Foucault for whatever reasons--maybe because he was homosexual?--raises questions about the meaning and function of confessional practice by questioning the reality of the repression it is supposed to off-set. He argues that historical evidence does not support the hypothesis of a general repression of sexuality in the nineteenth century but, on the contrary, indicates an expansion of discourses and a proliferation of discursive centers. Repression may have operated in certain areas at certain times, but these silences were nothing compared to the surrounding explosions of speech. General repression is not an historical fact. Therefore, confession is not the liberation of a sexuality that history and power have distorted and suppressed; it is not the doorway through which the natural, untainted essence of human being will come forth.

What, then, is confession? And what is this sexuality that, in the absence of general repression, insists on speaking so loudly about itself? Undoubtedly, confessional practices employed in psychiatry,psychoanalysis, 
medicine, criminology, and dozens of other disciplines do enable the expression of something--but what? What is the sexuality that is compelled to confess itself in these discourses? And whence that compulsion?

What is sexuality? This is Foucault's question. Implicit in it is another question--what is homosexuality?--the question I naively asked at the age of twelve, the question to which definitive answers have unceasingly come forth. But Foucault's question disrupts the grounds of those definitive answers. When we move with this question into Foucault's genealogical discourse, we undergo a shifting of the ground of questioning itself. For, raised within an analysis characterized by attention to history and power, questions are transformed, made new, which means there are possibilities for new kinds of answers, answers that do not foreclose thinking before it gets underway. Within genealogical discourse, the question becomes: What is sexuality (and in particular homosexuality), not essentially, but discursively and historically?

Foucault's shifting of the ground of questioning is analogous to that which occurs in section 3 of Nietzsche's Preface to On the Genealogy of Morals. There Nietzsche writes that as a child he pondered the essence and origin of evil. What is evil? From whence does it come? He assumed that the answers to these questions would concern things that lay "behind the world."2 Older and better educated, however, he ceased to assume that evil is historically transcendent, that the word "evil"refers to something outside language and the history of human struggle and desire. The being and source of evil, he reasoned, is an historical matter, and the answers--for there will be many answers--are to be found in the vicissitudes of discourse and power. The questions to ask are: What powers speak in the word "evil"? Whose interests does the concept serve? How does it function in different historical locations? From what concepts does it distinguish itself at what times? What are its immediate predecessors? What contingencies allowed for the emergence of this term in its current meanings and usages? This shift from the transcendent to the historical initiates Nietzschean genealogy. It is a simple shift. It requires only that one seek the meaning of words within rather than outside language, only that one abandon the notion that words' true meanings are their current referents and that one understand language as thoroughly historical. But the consequences of the shift are far more

\footnotetext{
${ }^{2}$ Friedrich Nietzshe, On the Genealogy of Morals, trans. Walter Kaufmann (New York: Vintage Books, 1967), p. 17.
} 
dramatic than the shift itself, and the fields opened by the questions it enables are fertile and vast.

What is sexuality? How has sexuality come to be the truth of human being? How is it that we have convinced ourselves that our sexuality, our truth, has for two centuries now been repressed and that in confessional practice our very freedom is at stake? How did sexual subjectivity come to be? These are Foucault's genealogical questions--the questions that seemed to hold such promise for me when I first encountered them ten years ago, the questions that opened the doors of possibility that every other sexual discourse had closed off, beginning with that conversation in the kitchen with my mother ten and a half years before.

\section{Sexual Subjectivity/Homosexual Subjectivity}

By pointing out that sexuality is essentially epistemological (in that it serves as an object of knowledge and a locus of truth), Foucault very clearly situates sexuality--all sexuality--in a problematics of concealment and disclosure. Sexuality is constituted from the beginning as that which must be confessed; sexuality is, inherently, something hidden that must be drawn out. The sexual subject, therefore, is constituted, in its very essence, as a confessing subject--whether its confession remains within the pages of the individual's diary or becomes an item in the daily news. The sexual subject confesses; the question is only what, when, where, and to whom.

The sexual subject, then, is pervaded by epistemological concerns; every aspect of its being is ordered by issues of truth and falsehood, knowledge and ignorance. Its constant engagement with the dynamics of the known and the unknown, the revealed and the concealed is the defining feature of its existence. Thus, Foucault's analysis situates sexual subjectivity--all sexual subjectivity--in relation to what has come to be known as the "closet." No matter what its individual nature, sexuality's initial locus is always a "closet," otherwise confession would have no meaning. The sexuality Foucault describes is perpetually exhorted to "come out," perpetually "coming out," and perpetually at risk of being "outted." Thus homosexual subjectivity--the popular exemplar of both "closeted" and "out" sexuality--is paradigmatic of sexual subjectivities of all sorts.

Those who criticize Foucault for paying scant attention to homosexuality overlook this crucial analytic move. Foucault does not make homosexuality an explicit object of consideration in The History of Sexuality precisely because homosexuality is the subject of the entire discourse. The 
subject position under investigation in this work is the subject constituted in relation to the closet, which is culturally marked as a homosexual space. One of the most central and perhaps radical claims in Foucault's work is that sexual subjectivity in the twentieth century is constituted-regardless of any individual's object choice or "orientation"--in relation to a homosexual subject position that was established in the nineteenth century. In section 3 of this essay I will explore this claim.

Given this description of sexual subjectivity, Foucault's analysis is likely to be especially compelling for a homosexual reader. One reads of oneself, one's dilemmas, one's suspicions, one's pleasures, one's fears. Perhaps for the first time, one reads of oneself not as deviant but as exemplary. One can take a certain perverse pleasure in this inversion of the normal order of things, but pleasure is not all a homosexual reader may take from Foucault's analysis. Power (which to be sure offers some pleasures of its own) is also to be had. As I will argue in the final section of this essay, recognition of the centrality of the homosexual subject can be liberating and empowering for those who occupy that subject position.

\section{Toward a Genealogy of the Homosexual}

Genealogies begin with the birth of the being to be accounted for. They note the supporting conditions at the time--those that brought forth the new creature and nurtured it--and then move back in history through the ever-increasing confluences of contingencies that engendered those supporting conditions. If one were to set out to write a genealogy of the homosexual, one would be drawn immediately to the last third of the nineteenth century when the word "homosexual" first found its way into language. Foucault suggests that "Westphal's famous article of 1870 on 'contrary sexual sensations' can stand as its date of birth" (HSI 43). One would note, then, that sexological discourse served as the matrix within which the embryo germinated and was nourished. One would also note two other facts: (1) the presence of a large number of other deviant sexual identities--"Krafft-Ebing's zoophiles and zooerasts, Rohleder's automonosexualists; and later, mixoscopophiles, gynecomasts, presbyophiles, sexoesthetic inverts, and dyspareunist women" (HS1 43)--and (2) the absence of anything called "heterosexual."

Given these observations, a genealogist would ask two broad questions: (1) What were the events, conditions, discourses, or institutions that enabled and supported all these reifications of sexual practice, including the homosexual, in the final third of the nineteenth century, and (2) what were the events, conditions, discourses, or institutions that 
nurtured the figure of the homosexual while allowing the deaths of its myriad siblings? Here one might take the heterosexual's absence as a clue.

Let us begin with the first question: What supported the reification of sexual practices in the nineteenth century? Varieties of sexual practice existed long before then. But late in the nineteenth century suddenly what had been conceived along the axis of activity was reconceived along the axis of identity. Whereas the sodomite was but the juridical subject of forbidden acts (HS1 43), the homosexual (among others) emerged as

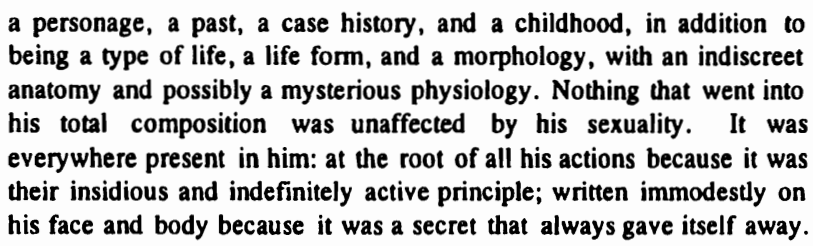

(HS1 43)

Whereas the sodomite was an outlaw and a sinner, the homosexual was a reified pathology; whereas the sodomite was an outlaw and a sinner because of what he or she did, the homosexual was a pathology regardless of anything he or she did or did not do.

As a "case, "a pathology, the homosexual's locus of emergence is sexological discourse, a branch of medical discourse, which by the nineteenth century is a branch of the life sciences. The homosexual is a child of biology and medicine. Therefore, careful examination of the relation between sexuality and "a technology of health and pathology" (HSI 44 ) is crucial to the construction of a genealogy of homosexuality. This examination will take us into Foucault's discussion of "biopower" (HSI 140). For it is within networks of biopower that sexuality is a matter of healthy functioning and that health means normality and pathology abnormality or deviance.

The genealogical account of biopower that Foucault offers is complex and highly compressed in The History of Sexuality, Volume 1. Nevertheless, an argument exists there in encapsulated form, its most important premiss being the following: In the last quarter of the eighteenth century an event of monumental importance occurred, "nothing less than the entry of life into history" (HS1 141).

This entry occurred in two different realms. On the one hand, it took place in the realm of discursive formation. Only at the end of the 
eighteenth century did the distinction between organic and inorganic beings become established as a significant demarcation in scientific practice, and only with this distinction were modern biological sciences born. As Foucault writes in The Order of Things,

\begin{abstract}
Historians want to write histories of biology in the eighteenth century; but they do not realize that biology did not exist then, and that the pattem of knowledge that has been familiar to us for a hundred and fifty years is not valid for a previous period. And that, if biology was unknown, there was a very simple reason for it: life itself did not exist. All that existed was living beings, which were viewed through a grid of knowledge constituted by natural history.
\end{abstract}

In fact the word "biology"did not enter scientific discourse until $1802 .{ }^{4}$ "Life"as we understand the term simply was not a scientific category prior to the end of the eighteenth century. On the other hand--and, Foucault implies, more fundamentally (HSI 143)--life emerges as the object of disciplinary power. It is the organism--as a growing, reproducing individual and as a member of a growing, reproducing population--that becomes the object of power's advance.

Only with the concept of "the organism" is it possible for disciplinary power to become normalizing power, biopower. In the seventeenth and early eighteenth centuries, when bodies were conceived of as collections of spatially-related parts, the purpose of discipline was to smooth the interactions of those parts, to make movements more efficient, to produce a body that functioned like a well-oiled machine. The concept of "the organism," however, allowed the introduction of the notions of temporality and development into disciplinary practice. An organism has functional systems, cycles of growth and decline; hence, its parts stand not in spatial relation, but primarily in temporal relation to one another. An organic body is essentially a body in process. ${ }^{5}$

This shift in the conception of the body--from machine to organism, from spatiality to temporality--marks the shift from mechanical disciplinary power to normalizing biopower. For only a temporal being can be normal or abnormal. Norms always concern development--stages

${ }^{3}$ Foucault, The Order of Things (New York: Vintage Books, 1970), pp. 127-28.

4Nancy Stepan, The Idea of Race in Science (London: Macmillan, 1982,p. 5.

'Foucault discusses this transmutation of disciplinary power in Discipline and Punish: The Birth of the Prison, trans. Alan Sheridan (New York: Vintage Books, 1977), pp. 155-56. 
of growth, of intellectual or moral attainment, of civilization. A being is normal when it progresses through the requisite set of stages in the right order at the right rate; a being is abnormal when it fails to progress through the stages in the right order, when it regresses, when its development is accelerated, retarded, or arrested at an early or intermediate stage.

The objects of biopower and of biological science are the same object--the organism. The aims of the two disciplines are the same as well. Biological science aims to generate organic developmental norms in order to devise ways of intervening in cases of abnormality. Similarly biopower aims to administer the processes of life, to manage populations and to discipline living individuals, which it does by generating norms--often taken from biology--and by developing ways to intervene in cases of abnormality. Biology and biopower are intimately connected.

By the end of the nineteenth century, medicine, which of course partakes of a discursive and practical tradition far older than biology, was securely framed within the discursive structure of the normalizing life sciences. It was a thoroughly normalized medical discipline that enabled the sub-fields of psychiatry and sexology, disciplines which in their turn produced "the homosexual."

In these new medical discourses, "homosexuality" is a coinage designating a specific type of abnormality, a specific deviation from a developmental norm. One becomes homosexual because, somewhere along one's developmental trajectory, the process of sexual maturation veers away from the standards of organic functioning established by medical science. Exactly what causes this deviation from the norm has always been disputed. But what is important for Foucault's purposes and for ours here is that the homosexual is formed from the beginning as an essentially developmental subject whose developmental process has gone awry. This may happen to anyone temporarily, but it becomes reified as a pathology if the deviation constitutes a permanent arrest of the developmental process. At that point, developmental deviation becomes personal identity.

This way of understanding deviance characterizes nineteenth-century sciences generally, from histology and embryology to anthropology and incipient sociology, all of which posited temporal progression, development, as a fundamental ontological category. But, since processes in themselves are difficult to study, arrested processes are essential for establishing a science of temporal unfolding. William Riply and other teratologists assembled extensive collections of deformed fetuses and stillborn animals and children, because by studying each stage in 
arrest, they hoped to learn about processes in their normal temporal flow. Similarly, anthropologists sought to understand the rise of human civilization by studying "primitive" groups, those whose civilized development remained arrested at an early stage. Though it may seem odd that sciences dedicated to the notion that temporal development is ontologically fundamental would insist on reification of deviant categories, in fact the practice of reification actually grounded those sciences' developmental claims. Studies of reified deviants were necessary in order to enable scientists to establish developmental norms.

The notion of arrested development in turn enabled technological interventions in development. If the process of deviation itself could be delineated, then scientists could, theoretically, intervene and force the organism back onto a normal developmental path. Intervention might occur in the lives of individuals--children might be saved from becoming auto-monosexualists, for example--or in whole populations--races might be purified and thus set on the road to progress. This was the promise of nineteenth-century biological science, working hand in hand with social and governmental institutions of biopower.

And they did work hand in hand. Deviance seemed rampant, but scientists, bureaucrats, technicians, and social reformers all promised frightened constituents that someday it would be eradicated. They held that deviance was a threat to all good citizens and even to the future of civilization itself; degeneration of families, races, and the entire species loomed. But there was hope. Better living through eugenics became the scientific, bureaucratic, and political order of the day.

However, if elimination of deviance was the aim of normalizing technologies, why did deviants--like homosexuals--remain? Foucault gives an implicit answer when he discusses the campaign against masturbation. "What appears," he writes, "is an effort at elimination that was always destined to fail and always constrained to begin again" (HS1 41). The effort to eliminate deviance establishes social structures and discourses that produce so much power (and pleasure), that in the end it is no more than a cover for the exercise and extension of bio-political networks. The effort to eliminate continues, then, only as a ruse.

\footnotetext{
What this actually entailed, throughout this whole secular campaign that mobilized the adult world around the sex of children, was using these tenuous pleasures as a prop, constituting them as secrets (that is, forcing them into hiding so as to make possible their discovery), tracing them back to their source, tracking them from their origins to their effects, searching out everything that might cause them or simply enable them to exist... The child's "vice" was not so much an enemy
} 
as a support.... Always relying on this support, power expanded, subdivided, and branched out.... In appearance we are dealing with a barrier system; but in fact, all around the child, indefinite lines of penetration were disposed.

(HS1 42)

Deviance had--and still has--at least two functions: (1) to enable the study and establishment of "normality, " and (2) to justify normalization of multiple sectors of a population. These two functions are inseparable from one another.

We may conclude, then, that among the conditions supporting reification of sexual practices in the nineteenth century, of greatest importance was the existence of power/knowledge regimes grounded in the notion of normed organic development. Reified sexual pathologies are unthinkable apart from discourses of development, maldevelopment, and developmental deviance and arrest, and they are invaluable within them as sources of new knowledge about development's normal processes. Further, in addition to serving as sources of knowledge, reified pathologies serve as targets for normalization, as the raison d'être for bio-political intervention in the lives of individuals and social groups.

We are now in a position to address the second genealogical question raised at the beginning of the present section: Why did the figure of the homosexual remain long after the other reified sexualities Foucault mentions suffered their demise? Foucault does not give an explicit answer, since he does not make the homosexual the object of his essay, but his work suggests at least one hypothesis.

For both analytic and political purposes, normalizing disciplines require deviance, but not all kinds of deviance serve disciplinary purposes equally well. Deviance to which few people are prone is of little use--because study of such subjects tells scientists little about society as a whole and because deviance that is not within the realm of most individuals' experience cannot serve as justification for regulating most individuals' behavior. While probably no one ever actually formulated the plan to regulate people's lives by inventing deviance and then frightening them with stories of it, it is a fact that (1) homosexuals do frighten people ${ }^{6}$-more than, for example, shoe fetishists or sheep-lovers; (2)

\footnotetext{
"As Eve Kosofsky Sedgwick notes in Epistemology of the Closet, "homosexual panic" has become a legal defense strategy for heterosexual men who assault gay men. The defense resis on the notion that many straight men are so afraid of homosexual advances, because they fear they may respond favorably to them at some level, that physical assault of the person alleged to have made advances is understandable. See Epistemology of the Closet
} 
homophobia is constantly reinforced in scientific and political discourse; and (3) homophobia makes people vulnerable to manipulation. Homosexuality, far more than other sexual deviations that were reified in the nineteenth century, implicated large sectors of the population and thereby enabled (partly by creating popular desire for) widespread regulation, manipulation, and control. Homosexuality proved to be very useful to disciplinary regimes.

Eve Sedgwick writes of the tension that exists in our society between what she calls the "minoritizing view" of homosexuality and the "universalizing view. ${ }^{77}$ On the one hand, homosexuality affects a minority of the population, because it is the condition (or nature) of a small group of people--somewhere between two and ten percent of us. On the other hand, homosexuality affects everyone, because it is that which most people seek not to be defined as, that against which most people define themselves, and that which their sexuality always threatens to become. On the one hand, only a few deviants are homosexual; on the other, anyone may turn out to be homosexual at any time. There is a conceptual gulf between homosexuality and heterosexuality, and at the same time they partake of the same conceptual arrangements; they are symbiotic. This tension is a key to understanding how disciplinary regimes structure and use homosexuality.

Heterosexuality, the norm, is a construct that did not exist prior to the conceptualization of homosexuality, but the two taken together are now believed--by most Americans at least--to exhaust the sexualities of the human species. He who is not heterosexual is homosexual, and vice versa. The norm has been established in opposition to the deviation, but that deviation is feared in part because anyone might slip into it. Thus it functions as a mechanism for controlling every individual in modern Western society. Those who are homosexual are compelled to confess and endure punishment or to spend life in silence and emotional exile from their families, neighbors, and colleagues. Those who are not homosexual are compelled to confess that they are not or to endure the punishments inflicted upon those who are. One must prove oneself sexually normal or be branded a queer--which is precisely the reason that homosexual deviance is so valuable to our society and why it remains when all its perverted kinspeople have died away: It is effective in disciplining entire

(Berkeley: University of California Press, 1990), p. 19.

'Sedgwick, p. 1. 
populations, whereas other, less binary-prone categories, do not afford that possibility to as great an extent. Homosexual deviance disciplines not just homosexuals, but everyone. The figure of the homosexual is the perfect tool of normalizing power.

What is a homosexual then? A homosexual is an historico-discursive construct arising with biologico-political networks of power; one very important reason it is retained is that it enables the management of a variety of sectors of the sexual population--in part by defining them, in part by punishing them, and in part by frightening them of society at large, their loved ones, and themselves. Over the hundred and twenty years since the homosexual became a species, it has been refigured in many ways, both by the administrative networks that supposedly seek to eliminate or manage it and by those who instantiate the category. Its exact definition, not just its value or legitimacy, has always been in dispute. Nevertheless, as Sedgwick forcefully argues, homosexuality and homophobia are fundamental organizing principles in our sexual and anthropological discourses and the disciplinary practices that accompany them. And, I would argue, homosexuality's conceptual instability is what makes it so strategically useful for disciplinary regimes. Far from being mere marginal characters ever threatened with annihilation by a homophobic society, homosexuals are central figures in a complex system of biopower that aims to administer sexually saturated, docile populations.

This is not to say individual homosexual people are not harassed, beaten, excluded from jobs and insurance programs, killed, and erased from cultural history. Clearly our society, both formally and informally, discriminates against and attempts to silence, injure, and even eliminate individual homosexual people daily. However, though these anti-homosexual social mechanisms look like a barrier system, as Foucault says about the mechanisms established ostensibly to prevent masturbation, they function like a system of incitement: they force homosexuality into closets so it can be tracked down and discovered or confessed; they enable the creation of lines of penetration into individuals' lives; they incite discourse; and, most importantly, they maintain sexuality as an epistemological issue, as a question of truth.

\section{Genealogy and Its Aftermath}

If one were to set out to write a genealogy of the homosexual, one would surely write something very like The History of Sexuality, Volume 1. Just as Nietzsche's book offered a genealogical answer to the question of 
morality, Foucault's book offers a genealogical answer to the question of sexuality. In Nietzsche's genealogy, evil--that which morality supposedly seeks to eradicate--functions as the central support for moral disciplinary regimes. Similarly, in Foucault's genealogy, the closet-the hiddenness that sexual discourses supposedly seek to penetrate and thereby discard--functions as the central support for sexual disciplinary regimes.

As we undergo the genealogical movement of Foucault's text, as the inevitability of our sexual identities comes to seem more and more questionable, rigid sexual categories lose their power to form us and to shape our understanding of the world. Some of us may experience this from the beginning as freeing. But for others, destabilization of the modes of thought that define us might well cause fear, anger, or a sense of humiliation. It is bad enough, perhaps, to be labelled deviant, immoral, or sick; but Foucault's label may be even worse, because Foucault is suggesting that we are products, "instrument effects" (HSI 48) of the powers that oppress us, its weapons. He is suggesting that we participate in our own oppression and that the means we have developed to combat it--naming ourselves, speaking of our sexuality and our lives--may provide further support for those powers. This genealogy implicates us.

Why, then, do I find it so exciting? The answer is simple. If one is implicated, one is not powerless. Foucault's answer to the question "what is a homosexual?" opens toward creative possibility, toward choice. There is nothing inevitable about the current epistemological and sexual arrangements in our society. There is nothing inevitable about anyone's participation in those arrangements. And, if I occupy a position that serves as a support for an entire oppressive system, my acts of disruption in that position may destabilize that system. By pointing out the centrality of homosexual subjectivity in regimes of sexual power/knowledge, Foucault points to homosexual subjects as powerful actors in determining the future of those power/knowledge regimes.

Foucault once said,

Maybe the target nowadays is not to discover what we are, but to refuse what we are. We have to imagine and to build up what we could be to get rid of this kind of 'double-bind,' which is the simultaneous individualization and totalization of modern power structures. ${ }^{8}$

${ }^{8}$ Foucault, "Afterword: The Subject and Power, "in Michel Foucault: Beyond Structuralism and Hermeneutics, 2nd ed., ed. Hubert L. Dreyfus and Paul Rabinow (Chicago: University of Chicago Press, 1983), p. 216. 
This genealogy of homosexuality opens onto a whole realm of new questions: What do we want to be? How can we destabilize the powers that depend on us? What modes of disruption will serve to alter the meanings of the practices we engage in? How can we incite the disruption of heterosexual categories, practices, and meanings? Unlike non-genealogical discourses, Foucault's attempt to answer the question "What is a homosexual?" makes creative thinking possible, opens questioning rather than foreclosing it.

Some might fear that genealogical thinking--assuming, as it does, that categories are historically constructed and insisting, as it does, on freedom--will lead to a rejection of homosexuality as a choice or to a demand that homosexual individuals simply choose heterosexuality. On the contrary, in the space of genealogy, neither the repression of homosexuality nor the strengthening of heterosexual norms is possible. Repression is merely an instrument of confessional power, and heterosexuality is a fragile concept thoroughly dependent for its meaning on homosexuality; heterosexuality, and therefore heterosexism, are at least as destabilized in this genealogical discourse as homosexuality is. Foucault does not join the chorus exhorting us to leave the closet, but he does not push us back into the closet either. Foucault's genealogy explodes the closet--and leaves us with an open future.

It is true that the self-overcoming movement of Foucault's genealogy undermines the very homosexual subject who informs and structures it, insofar as that subject maintains itself in an insistence upon its ahistoricity. That is the nature of Nietzschean genealogy; it leaves no transcendent essences intact. But in the end, genealogy gives far more than it takes away. In the end, it gives us ourselves, for it gives us the freedom "to imagine ... what we could be."

University of Richmond

LADELLE MCWHORTER 